\title{
Island effect on diversity, abundance and vegetation structure in the Chocó Region
}

\author{
Edier Soto Medina ${ }^{1 *}$, Ana Isabel Vásquez ${ }^{1}$, Maria Paula Moreno ${ }^{1}$ and Alba Torres-González ${ }^{1}$
}

Received: June 15, 2015. Accepted: July 11, 2015

\begin{abstract}
The aim of this study was to evaluate the effect of island area and isolation on species richness and abundance, and vegetation structure of Isla Palma by comparing these parameters with those of the continental location, Playa Chucheros. By sampling vegetation at each locality using Gentry transects (10 50x2 m) we found 204 species of plants at Playa Chucheros, and 103 on Isla Palma. Species richness and abundance of woody plants was higher for Playa Chucheros (472 individuals) compared to Isla Palma (349 individuals). Richness estimators indicate that the plant species richness of Playa Chucheros is almost twice as high as that of Isla Palma. Rarefaction curves suggest that Playa Chucheros had a significantly greater richness than Isla Palma. Furthermore, physiognomic parameters were higher for Playa Chucheros than those observed for Isla Palma, showing that the former supports tree vegetation with higher DBH and greater height. These results indicate that the size and isolation of the island is reflected in a diminished richness and vegetation structure, which can be of significant assistance in the development of better conservation strategies for plants and other groups of organisms on islands.
\end{abstract}

Keywords: Chocó, Chucheros, Gentry transect, Isla Palma, Island, physiognomy, richness, vegetation

\section{Introduction}

The study of past and present distribution of organisms and the factors that regulate them is known as biogeography. This discipline aims to define, characterize and understand the history of communities of flora and fauna patterns to make predictions about how biodiversity will respond to different changes. For this, islands have been great tools because they can be used as laboratories, since they represent real systems of a small size that are replicated around the world (Kueffer \& Fernández-Palacios 2010). This theory has also had a huge impact on conservation biology, highlighting the importance of reserve size and connectivity in maintaining species diversity and stimulating countless investigations on fragmented ecosystems (Laurance 2008). However, the model of island biogeography focuses only on the effect of area and isolation on species richness, but ignores other factors such as fragmentation, edge effects, the underlying matrix, among others (Laurance 2008). These factors have a strong influence on diversity, but they have been evaluated only in fragmented systems, and not in islands.

For several years two theories of island biogeography have coexisted. In 1967, MacArthur \& Wilson proposed that the number of species in an island reflects a dynamic balance between immigration and extinction rates, influenced by the size and isolation of the island. Larger islands have more niches and resources, allowing entry and sustenance of a greater number of species; moreover, islands closest to the mainland have more species to increase the probability of colonization from the source. On the other hand, some authors such as Rosen (1976), Nelson \& Platnick (1981) using several models, suggested a new one called vicariance biogeography. They assumed that speciation events are caused by isolation with little or no colonization and extinction. However, recent publications have documented patterns that include no just the two models but also new aspects, shaping the beginnings of a new paradigm (Heaney 2007).

Currently, this theory has been extended to the design of nature reserves, which can be understood as patches or "islands" of natural habitats to preserve among a less favorable matrix: eg. agriculture or urban areas (Higgs 1981). It has also been proposed to test new methods to restore biotic interactions in ecosystems affected primarily by anthropogenic activity (Kaiser-Bunbury et al. 2010). Nevertheless, few studies have been done to analyze the patterns of richness, abundance and structure of vegetation on islands and the factors that control them, and

\footnotetext{
${ }^{1}$ Grupo de Ecología y Diversidad Vegetal, Departamento de Biología, Facultad de Ciencias Naturales, Universidad del Valle, 13 N. 100-00, Cali, Colombia

* Corresponding author: ediersot@gmail.com
} 
even in the Chocó Region, a renowned area for being one of the twenty-five biodiversity hotspots in the world for its great diversity and endemism (making it a priority for conservation efforts), such studies are still lacking (Myers et al. 2000).

Using Gentry's method (Gentry 1982a), which uses a belt transects divided into ten rectangular plots of $50 \mathrm{~m}$ $\times 2 \mathrm{~m}$ for a total area of $1000 \mathrm{~m}^{2}$, the diversity, abundance and structure of woody plant community with a diameter at breast height (DBH) greater than $2.6 \mathrm{~cm}$ was sampled in Isla Palma, located on the Pacific Ocean coast of Valle del Cauca and compared with Playa Chucheros, a very close town in Málaga Bay, in order to assess the effects of the area and isolation of the island on its plant community.

\section{Materials and methods}

\section{Study Area}

The two sampling sites belong to the Chocó region, specifically the Pacific coast of Valle del Cauca, Colombia. The vegetation of this region is mainly tropical rainforest (Rangel \& Arellano 2004). In Bahia Málaga Bay region there are two annual periods of high rainfall, the first one in September to November and the other one with less intensity in April to May. The average annual rainfall is $6000 \mathrm{~mm}$ and the relative humidity is 90\% (Amaya 2004; Castellanos 2003). Isla Palma is located in Málaga Bay ( $3^{\circ} 53>\mathrm{N}, 77^{\circ} 21>\mathrm{W}$ ), north of the port of Buenaventura, it has an area of 138 ha and it's surrounded by rocky cliffs evenly distributed with heights between 6 and $15 \mathrm{~m}$. It also has sandy beaches that are exposed to low tide. Due to high rainfall in the area and the topography of the island there are several outputs of freshwater towards the sea, where these have a slight mixture with salt water (Giraldo et al. 2012). On the other side, Playa Chucheros is located at the entrance to Málaga Bay opposite to Isla Palma ( $\left.3^{\circ} 53^{\prime} \mathrm{N} ; 77^{\circ} 21>\mathrm{W}\right)$. This place is dominated by tropical rainforest, with some mangrove areas. Playa Chucheros is surrounded by cliffs up to $18 \mathrm{~m}$ high, which are separated from the sea by a sandy beach (Cantera et al. 1998).

\section{Sampling}

Ten belt transects $(50 \mathrm{~m} \times 2 \mathrm{~m})$ were made in the two locations (Gentry 1982a; b): Isla Palma in November 2008 and Playa Chucheros in January 2014. Only woody plants with a diameter at breast height (DBH) greater than 2.6 $\mathrm{cm}$ were considered. For each tree DBH and total height were measured. Specimens were identified in field at the lowest possible taxonomic level (Gentry 1993) and those that could not be identified were collected and brought for identification to the CUVC Herbarium of the University del Valle. Fertile specimens were included in the collection of the CUVC Herbarium.

\section{Data Analysis}

Based on the records, abundance, $\mathrm{DBH}$, average height and average species richness (alpha diversity) per transect were estimated. Beta diversity for each locality was also calculated as the average Sørensen index of all comparisons per couple among the ten transects. These parameters were compared for the two locations using Student's t-tests. Gamma diversity was obtained as the total number of species per locality and the first order richness estimators Jackknife, Chao 1 and Bootstrap were also used (Gotelli \& Graves 1996; Colwell 2005). These estimators were used because they allow to evaluate the sampling effort, to correct the effect of very large differences in the abundance of plants between two locations on comparisons of species richness, rarefaction curves were made with respect to the lowest number of individuals (Gotelli \& Graves 1996). Analyzes were performed using Statistica 7.0 (StatSoft 2004) EstimateS 8.2 (Colwell \& Elsensohn 2014) and PAST (Hammer et al. 2001).

\section{Results}

\section{Floristic composition}

We found 204 species of plants in Playa Chucheros, and 103 in Isla Palma. The dominant species in Playa Chucheros were Attalea sp.1, Faramea sp.3, and Miconia aponeura, while in Isla Palma Brosimun cf. utile, Palicourea sp.1, Miconia sp.1 and Piper rio-cajambrense were dominant. Regarding to families, those with the biggest abundance in Playa Chucheros were Rubiaceae, Arecaceae, Lecythidaceae and Melastomataceae, while in Isla Palma they were Melastomataceae, Rubiaceae, Moraceae, Piperaceae, Arecaceae and Fabaceae (Tab. 1). In terms of number of species, the dominant families in Playa Chucheros were Rubiaceae (17), Sapotaceae (14), Annonaceae (13), Clusiaceae, Fabaceae, Lauraceae and Lecythidaceae (10), while in Isla Palma they were Melastomataceae (nine), Fabaceae (seven), Annonaceae (six) and Arecaceae (five).

\section{Diversity for Locality}

Species richness and abundance of woody plants was higher for Playa Chucheros (472 individuals) than for Isla Palma (349 individuals). The species accumulation curves show a non-asymptotic pattern for the two locations, although the slope is steeper for Playa Chucheros (Fig. 1). The richness estimators indicate that the species richness of plants for Playa Chucheros is almost twice times greater than that of Palma Island (Tab. 2). The sampling efficiency was similar for the two locations. Because in Chucheros more individuals were sampled than in Isla Palma, richness was compared by rarefaction according to the number of individuals found in Isla Palma. Rarefaction curves suggest 
Table 1. Dominant plant species and families in Playa Chucheros and Isla Palma.

\begin{tabular}{|c|c|c|c|c|c|c|c|}
\hline \multicolumn{4}{|l|}{ Playa Chucheros } & \multicolumn{4}{|l|}{ Isla Palma } \\
\hline Species & & Families & & Species & & Families & \\
\hline Attalea sp. & 43 & Rubiaceae & 84 & Brosimum cf. utile & 27 & Melastomataceae & 34 \\
\hline Faramea sp. 3 & 32 & Arecaceae & 83 & Palicourea sp.1 & 26 & Rubiaceae & 31 \\
\hline Miconia aponeura & 24 & Melastomataceae & 42 & Miconia sp.1 & 26 & Moraceae & 30 \\
\hline Manicaria saccifera & 21 & Lecythidaceae & 21 & Piper rio-cajambrense & 22 & Piperaceae & 27 \\
\hline Mabea occidentalis & 10 & Euphorbiacea & 18 & Cecropia cf. alvareziana & 19 & Arecaceae & 23 \\
\hline Faramea sp.4 & 9 & Sapotaceae & 18 & Pouteria sp.1 & 12 & Fabaceae & 22 \\
\hline Faramea sp.6 & 9 & Chrysobalanaceae & 15 & Quararibea sp.1 & 12 & Cecropiaceae & 19 \\
\hline \multirow[t]{8}{*}{ Lecythidaceae sp.1 } & 9 & Annonaceae & 13 & Bactris aff. gasipaes & 11 & Annonaceae & 17 \\
\hline & & Clusiaceae & 13 & Annona sp.2 & 11 & Bombacaceae & 12 \\
\hline & & Lauraceae & 12 & Cyclanthaceae sp.1 & 10 & Flacourtiaceae & 12 \\
\hline & & Malvaceae & 12 & & & Sapotaceae & 12 \\
\hline & & Fabaceae-Mimosoidea & 11 & & & Cyclanthaceae & 10 \\
\hline & & Myrtaceae & 11 & & & Euphorbiaceae & 10 \\
\hline & & Meliaceae & 10 & & & & \\
\hline & & Myristicaceae & 10 & & & & \\
\hline
\end{tabular}
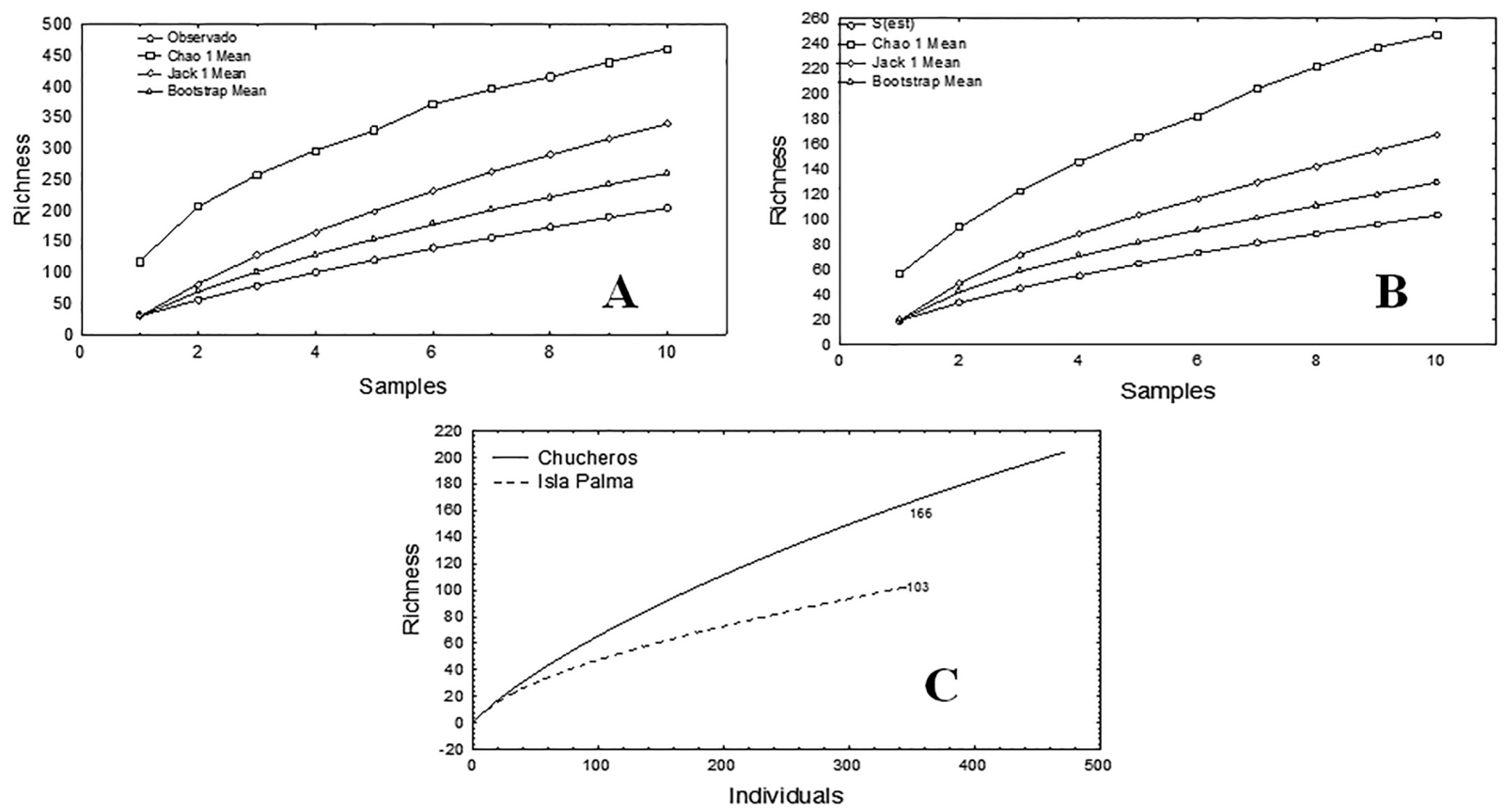

Figure 1. Species accumulation curves for Chucheros (A) and Isla Palma (B), and rarefaction curve (C).

Table 2. Species richness and richness estimators for Playa Chucheros and Isla Palma.

\begin{tabular}{cccccccc}
\hline Locality & Morphospecies & Jackknife 1 & Efficiency(\%) & Chao 1 & Efficiency(\%) & Boostrap & Efficiency(\%) \\
\hline Chucheros & 204 & 339.90 & 60.02 & 461.88 & 44.17 & 260.43 & 78.33 \\
Isla Palma & 103 & 166.90 & 61.71 & 246.59 & 41.77 & 129.22 & 79.71 \\
\hline
\end{tabular}


that Playa Chucheros had a significantly greater richness than Isla Palma (Fig. 1C).

\section{Comparison diversity alpha, beta, abundance and structure}

Alpha diversity on average, was found to be higher for Playa Chucheros (30 species) against Isla Palma (ca. 19 species) $(\mathrm{P}<0.01)$, although the last one showed a greater range of variation ( $\mathrm{SD}=7.87 \mathrm{vs}$. $\mathrm{DS}=4.85)$ (Fig. 2 ). The richness per transect was more homogeneous in Playa Chucheros (Chi square $\mathrm{p}=0.93$ ), whereas in Isla Palma it was adjusted to a Poisson distribution (Chi square $\mathrm{P}=0.38$ ). It was also observed that the abundance per transect was significantly higher for Playa Chucheros $(\mathrm{P}=0.01)$, but the variation in abundance between transects was higher for Palma Island ( $\mathrm{DS}=11.51$ vs. $\mathrm{SD}=5.81)$. Beta diversity was higher for Playa Chucheros $(\mathrm{P}<0.01)$ and the variation of this was the same for both locations (Tab. 3).

Furthermore, physiognomic parameters were higher for Playa Chucheros than those observed for Isla Palma, showing that the former supports tree vegetation with higher DBH and height (Tab. 3). The diameter classes have markedly different patterns with greater dominance of small trees and a few large trees in Isla Palma (Fig. 3), while in Playa Chucheros, although dominated by relatively thin trunks of trees, more individuals were found in other diameter classes compared to Isla Palma (Fig. 3).

\section{Discussion}

\section{Floristic composition}

Patterns of species richness and abundance in islands have been widely studied throughout history for various groups of organisms. However, there have been few investigations of island biogeography for vegetation, and how the structural parameters of vegetation vary in these systems has never been evaluated. Moreover, in the Chocó biogeographic region this kind of research has never been conducted, despite the fact that the region is an area of high diversity and high endemism (Rangel \& Rivera-Díaz 2004).

Several plants found in study are threatened. One of these species is Magnolia chocoensis, which is classified as Endangered B1 by IUCN (2001), because their known populations in this region are scarce and are decreasing. This is an endemic species of the Chocó region and it is used as timber. Other species to some extent threatened are: Eschweilera sclerophylla (Vulnerable B1) and Licania velata (Endangered B1). We also found species that usually inhabit lowland forests in good conditions

\section{Richness of plants}

Richness of tree and shrub species found in Playa Chucheros is similar to the one found in Bajo Calima (265 species) (Gentry 1982b), Gulf of Tribuga (208 species) (Galeano 2002) and Piangüita (407 species with DBH $\geq 1$
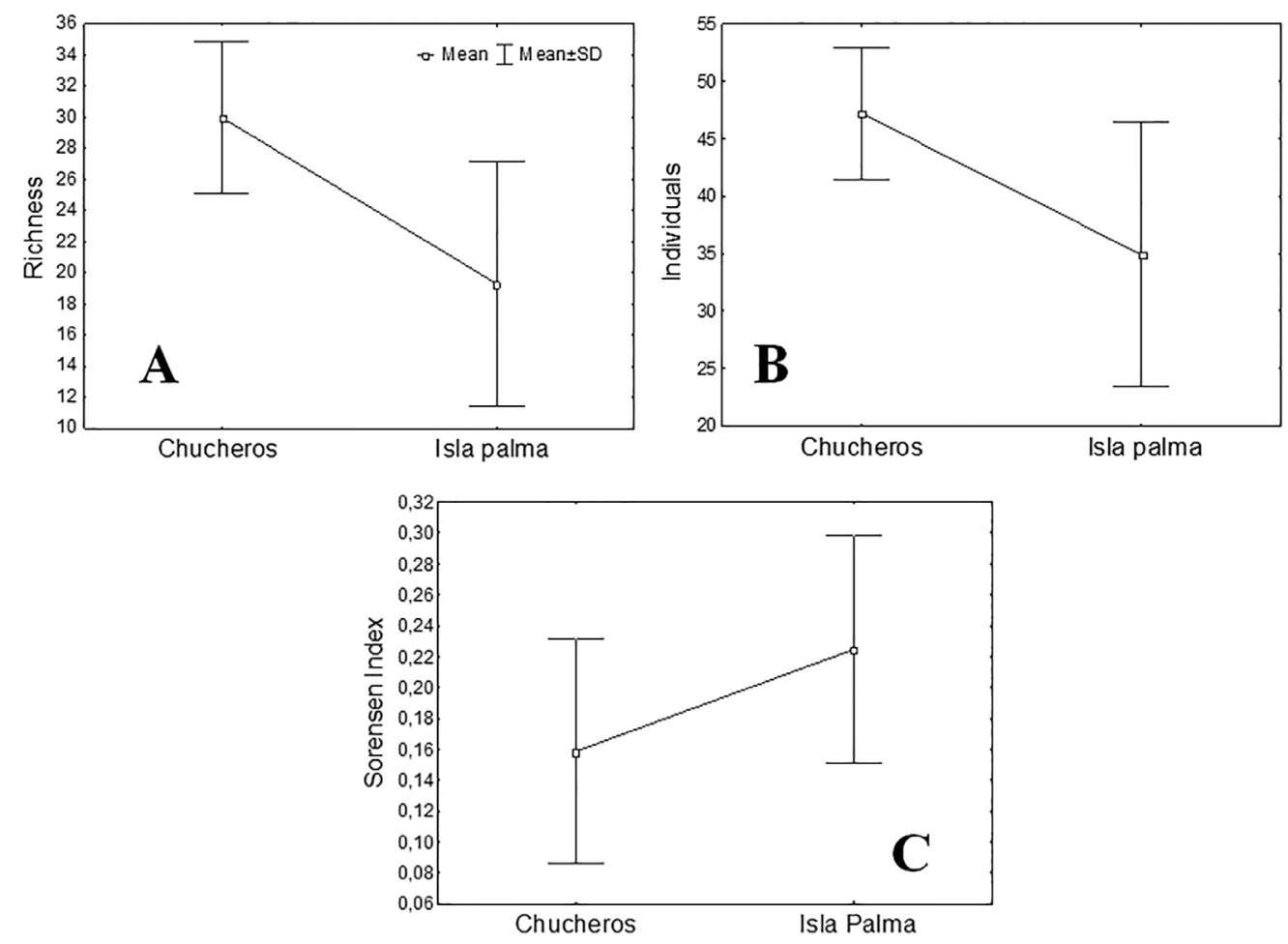

Figure 2. Comparison of richness, beta diversity and abundance between the two locations. 
Table 3. Summary of alpha and beta diversity, abundance, height and DBH, and t-tests.

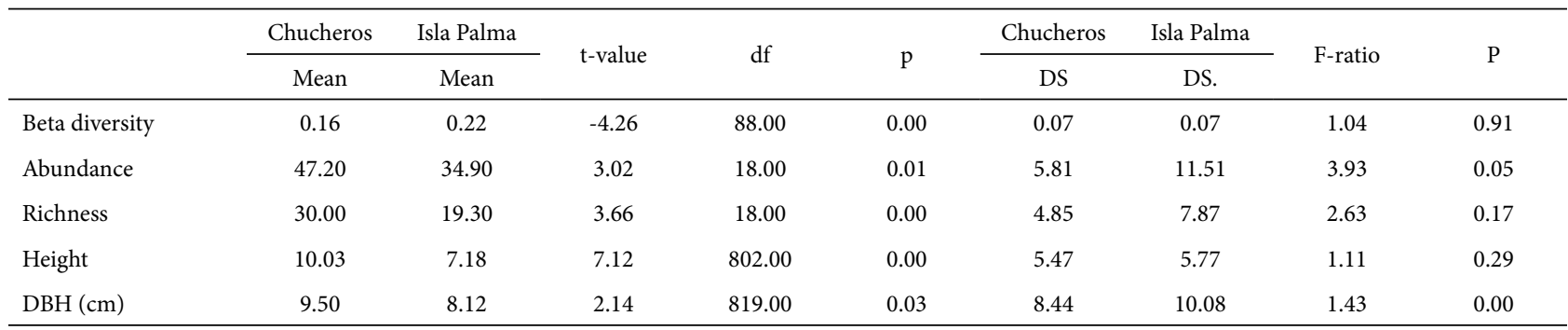
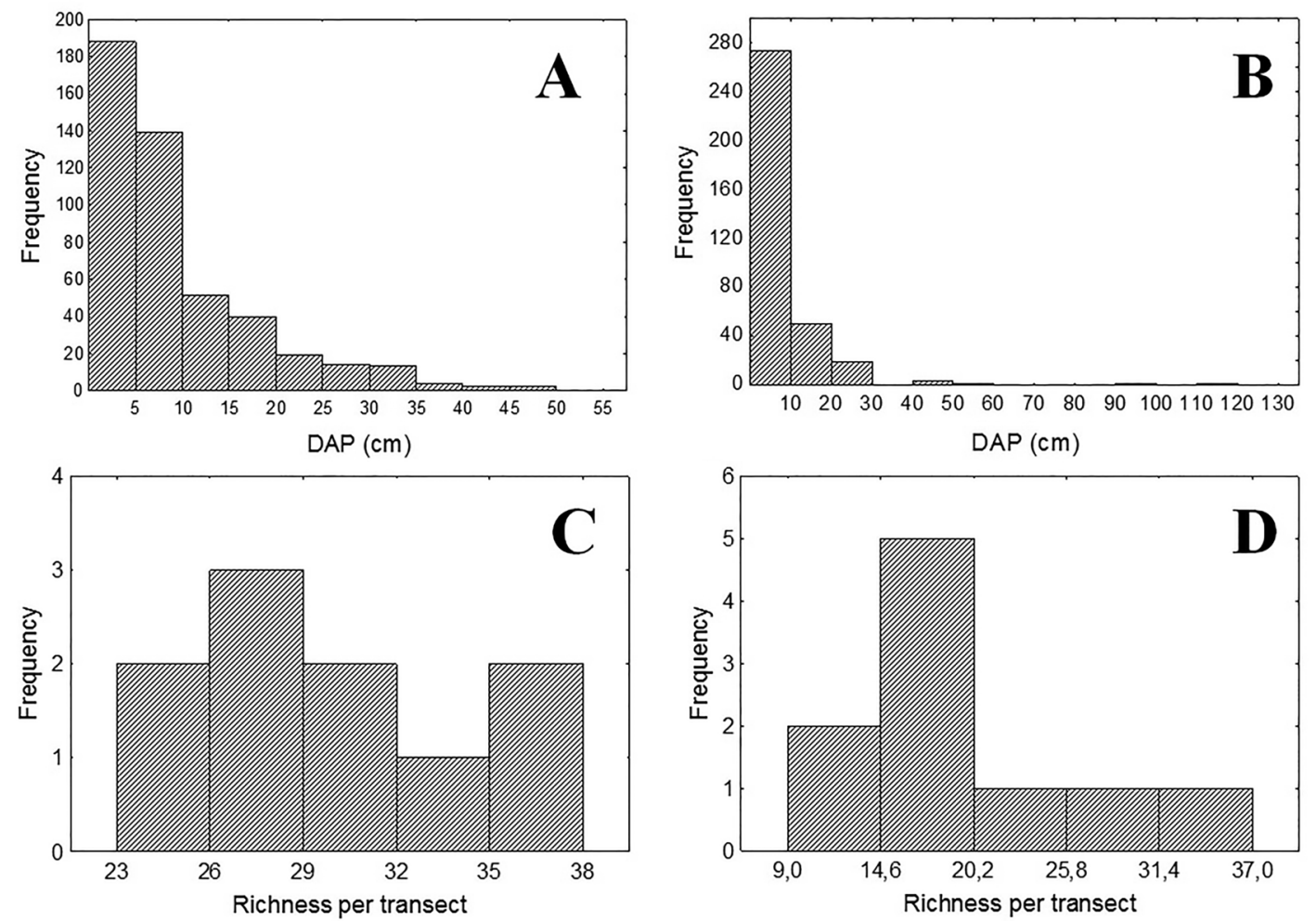

Figure 3. Histograms of DBH (cm) for Playa Chucheros (A) and Isla Palma (B), to the richness per transect with a homogeneous pattern for Playa Chucheros (C) and Poisson pattern Isla Palma (D).

cm) (Vásquez-Vélez et al. 2013). Species richness per transect for Playa Chucheros is also similar to that reported by other authors for the area (30 species Chucheros: 42-48 Bajo Calima species: 29 species Tribuga) (Gentry 1982b; Galeano 2002). On the other hand, plant richness in Isla Palma is considerably lower (103 species, ca. 20 per transect) than what is expected in lowland forests, suggesting that the area may be responsible for these low levels of richness. The richness of plant species on islands is determined by the combination of factors such as isolation from the source of plants, the size of the island, geology, geomorphology, soil characteristics, age and disturbance regime (MuellerDombois \& Fosberg 1998; Leigh et al. 2007). These factors also have a strong influence on structure of vegetation in islands (Leigh et al. 2007).
The area and isolation affect immigration rates (isolation), extinction and formation of new species (area) (MacArthur \& Wilson 1967): as a result, the smaller and more isolated the island is, the smaller the number of species it will have. The diversity that supports an island is the result of a dynamic balance between immigration and extinction rates (MacArthur \& Wilson 1967). On the other hand, the area itself is a determining factor in the number of species that an island can have: the greater the area, the more individuals may be present on an island, and consequently the more likely it is to contain more species (MacArthur \& Wilson 1967; Rosenzweig 1995). This area effect seems to have a very important role in determining the richness of plants (Ames et al. 2012). Thus, the size of Isla Palma can be the cause of a lesser richness than in Playa Chucheros. 
Laurence (2008) found that sample size affects both size and richness of trees, due to a disturbance regime that is higher in smaller fragments, which eliminates larger trees and reduces richness. Because of this, the most disturbed areas tend to have lower richness and density of trees (Laurance et al.1997; Larance et al. 2000; Laurance 2008). Thus, it is likely that a larger disturbance regime of Isla Palma compared to Chucheros causes this decrease in richness. As for richness variation in Isla Palma, it is likely to be caused by the cone shape of the island, which increases the effect of the wind and heavy rain in its narrowest part. This implies that the vegetation is not disturbed homogeneously throughout the island.

\section{Abundance and structure of vegetation}

The structure of vegetation of both locations was similar to those found in other locations in the region (Gentry 1986; 1993; Balslev et al. 1987; Gentry \& Terborgh 1990; FaberLangendoen \& Gentry 1991; Ferreira \& Rankin-de-Mérona 1998), although the structural parameters were significantly higher for Playa Chucheros. The pattern of dominant trees with small DBH, diametric classes $j$-shaped inverted, is common in these areas, which is due to the high dynamics of the flora as a result of the fall of large trees by heavy rains (Gentry 1986; 1993; Faber-Langendoen \& Gentry 1991). These areas are also characterized by a high density of trees, although this may vary as a result of the disturbance and soil unstability (Gentry 1986; 1993; Galeano 2002). Another factor that has been proposed to explain changes in these parameters, is the presence of bodies of water (Galeano et al. 1998), which decrease the density and richness of plants.

The vegetation structure is indirectly affected by island size. Tropical rainforest areas are characterized by rain during most times of the year, whichin times of high rainfall, tends to be very strong (Rangel \& Arellano 2004) becoming a disturbance factor in these ecosystems. High precipitation causes soil instability, which also promotes falling trees, especially at the edges (Gentry 1986; 1993; Faber-Langendoen \& Gentry 1991). In addition, the inlet water "washes" soil seeds, which decreases the turnover of individuals on the island. Increased windshear forces near edges can cause elevated rates of tree mortality that alter forest structure and composition (Chen et al. 1992; Laurance et al. 1997; 2000; Laurance 2008).This combination of effects causes small size (height and diameter) trees with a lower densityin their distribution. The smaller the island is, this effect becomesmore notorious, so in small islands it is expected to find a lower plant structure compared with the mainland. Edge effects may be especially important in fragments of dense forest, where the dark, humid microclimate contrasts notoriouslywith the dry, harsh, windy conditions of surrounding open habitats (Harper et al. 2005). Edge phenomena tend to increase in intensity as fragment size diminishes, creating a confounding intercorrelation between edge and area effects in fragmented landscapes (Laurance 1991). Because of this, the vegetation of Isla Palma present structural characteristics of secondary forest, but contains species of primary forest.

\section{Conclusions}

To our knowledge, this study is the first to address the Island effect on the richness and vegetation structure in the Chocó. By showing that island size and isolation are reflected in a diminished richness and vegetation structure, these results can significantly contribute to the development of better conservation strategies for plants and other groups of organisms. It is likely that both the area and a higher rate of disturbance in Isla Palma contribute to explain the lower richness and the presence of smaller trees in this island. Further research isrequired in these unexplored areas, given their importance as reservoirs of great diversity and endangered species, and that can be used to assess the real impact of high deforestation occurring in this region.

\section{Acknowledgments}

We thank the Universidad del Valle for financing the project through the Internal Call for research projects funding 2013. Also to Johan Home, Martin Llano and Mauricio Posada for their help in field work and sample identification, and Felipe Vejarano, Viviana Londoño and Alberto Giraldo for reviewing the manuscript.

\section{References}

Amaya VV. 2004. Relaciones ecológicas entre Echinometra vanbrunti y la macrofauna asociada a sus cavidades de habitación en el acantilado verde de Isla Palma, Bahia Malaga, pacífico colombiano. Monograph, Universidad del Valle, Colombia.

Ames S, Pischke K, Schoenfuss N, et al. 2012. Biogeographic patterns of lichens and trees on islands of the Boundary Waters Canoe Area Wilderness. BIOS 83: 145-154.

Balslev H, Luteyn J, Ollgaard B, Holm-Nielsen JB. 1987. Composition and structure of adjacent unflooded and floodplain forest in Amazonian Ecuador. Opera Botanica 92: 37-57.

Cantera JRK, Neira OR, Ricaurte C. 1998. Bioerosión en la Costa Pacífica Colombiana: Un estudio de la biodiversidad, la ecología y el impacto humano de los animales destructores de los acantilados rocosos. Bogotá, Fondo José Celestino Mutis, FEN.

Castellanos GA. 2003. Interacciones tróficas y espaciales de un ensamblaje de peces de charcos intermareales en un acantilado rocoso tropical, Bahía Malaga-Pacífico Colombiano. Monograph, Universidad del Valle, Colombia.

Chen J, Franklin JF, Spies TA. 1992. Vegetation responses to edge environments in old-growth Douglas-fir forests. Ecological Applications 2: 387-396.

Colwell RK. 2005. EstimateS (v. 7.5b1), Copyright RK Colwell: http:// viceroy.eeb.uconn.edu/estimate.

Colwell RK, Elsensohn JE. 2014. EstimateS turns 20: statistical estimation of species richness and shared species from samples, with non-parametric extrapolation. Ecography 37: 609-613.

Faber-Langendoen D, Gentry A. 1991. The structure and diversity of rain forests at Bajo Calima, Choco region, Western Colombia. Biotropica 23: 2-11. 
Ferreira LV, Rankin-de-Mérona JM .1998. Floristic composition and structure of a one-hectare plot in terra firme forest in Central Amazonia. In: Dallmeier F, Comiskey JA. (eds.) Forest Biodiversity in North, Central and South America and the Caribbean: Research and Monitoring. Carnforth, Parthenon Publishing Group. p. 649-662.

Galeano G. 2002. Estructura, riqueza y composición de plantas leñosas en el golfo de Tribugá, Chocó-Colombia. Caldasia. 23: 2-11.

Galeano G, Suárez S, Balslev H. 1998. Vascular plant species count in a wet forest in the Chocó area on the Pacific coast of Colombia. Biodiversity and Conservation 7: 1563-1575.

Gentry AH. 1982a. Neotropical floristic diversity: phytogeographical connections between Central and South America, Pleistocene climatic fluctuations, or an accident of the Andean orogeny? Annals of the Missouri Botanical Garden 69: 557-593.

Gentry AH. 1982b. Patterns of neotropical plant species diversity. Evolution Biology 15: 1-84.

Gentry AH. 1986. Species richness and floristic composition of Chocó region plant communities. Caldasia 15: 71-79.

Gentry AH. 1993. A Field guide to the families and genera of woody plants of Northwest south America (Colombia, Ecuador, Peru) with supplementary notes on herbaceous taxa. Washington, Conservation International.

Gentry AH, Terborgh J. 1990. Composition and dynamics of Cocha Cashu «mature» floodplain forest. In: Gentry A. (ed.) Four Neotropical Rainforests. New York, Yale University Press. p. 542-565.

Giraldo A, Garcés-Restrepo MF, Carr JL, Loaiza J. 2012. Tamaño y estructura poblacional de la tortuga sabaletera (Rhinoclemmys nasuta, Testudines: Geoemydidae) en un ambiente insular del Pacífico colombiano. Caldasia 34: 109-125.

Gotelli N, Graves GR. 1996. Null models in ecology. Washington, Smithsonian Institution Press.

Hammer Ø, Harper DAT, Ryan PD. 2001. PAST: Paleontological statistics software package for education and data analysis. Palaeontologia Electronica 4: 9pp.

Harper KA, Macdonald SE, Burton PJ, et al. 2005. Edge influence on forest structure and composition in fragmented landscapes. Conservation Biology 19: 768-782.

Heaney LR. 2007. Is a new paradigm emerging for oceanic island biogeography? Journal of Biogeography 34: 753-757.

Higgs AJ. 1981. Island biogeography theory and nature reserve design. Journal of Biogeography 8: 117-124.

IUCN. 2001. IUCN Red List Categories and Criteria: Version 3.1. IUCN Species Survival Commission. Gland, Switzerland and Cambridge, IUCN.

Kaiser-Bunbury CN, Traveset A, Hansen DM .2010. Conservation and restoration of plant-animal mutualisms on oceanic islands. Perspectives in Plant Ecology, Evolution and Systematics 12: 131-143.
Kueffer C, Fernandez-Palacios JM .2010. Comparative ecological research on oceanic islands. Perspectives in Plant Ecology, Evolution and Systematics 12: 81-82.

Laurance WF. 2008. Theory meets reality: How habitat fragmentation research has transcended island biogeographic theory. Biological Conservation 141: 1731-1744.

Laurance WF. 2010. Habitat destruction: Death by a thousand cuts. In: Sodhi N, Ehrlich P. (eds.) Conservation Biology for All. Oxford, Oxford University. p. 73-87.

Laurance WF, Delamonica P, Laurance SG, Vasconcelos H, Lovejoy TE. 2000. Rainforest fragmentation kills big trees. Nature 404: 836 .

Laurance WF, Laurance SG, Ferreira LV, Rankin-de-Mérona J, Gascon C, Lovejoy TE. 1997. Biomass collapse in Amazonian forest fragments. Science 278: 1117-1118.

Leigh EG, Hladik A, Hladik CM, Jolly A. 2007. The biogeography of large islands, or how does the size of the ecological theater affect the evolutionary play? Revue d Ecologie-la Terre Et La Vie 62: 105-168.

MacArthur RH, Wilson EO. 1967. The theory of island biogeography. New Jersey, Princeton University Press.

Mueller-Dombois D, Fosberg FR. 1998. Vegetation of the tropical Pacific Islands. New York, Springer-Verlag.

Myers N, Mittermeier RA, Mittermeier CG, Fonseca GA, Kent J. 2000 Biodiversity hotspots for conservation priorities. Nature 403: 853-858.

Nelson G, Platnick N. 1981. Systematics and biogeography: cladistics and vicariance, New York, Columbia University Press.

Rangel O, Arellano H. 2004. Clima del Chocó Biogeográfico de Colombia. In: Rangel O. (ed.) Colombia Diversidad Biótica IV: El Chocó Biogeográfico/ Costa Pacífica. Bogotá, Instituto de Ciencias Naturales. p. 39-82.

Rangel O, Rivera-Díaz O. 2004. Diversidad y Riqueza de Espermatófitos en el Chocó Biogeográfico. In: Rangel O. (ed.) Colombia Diversidad Biótica IV: El Chocó Biogeográfico/ Costa Pacífica. Bogotá, Instituto de Ciencias Naturales. p. 83-104.

Rosen DE. 1976. A Vicariance model of the Caribbean biogeography. Systematic Zoology 24: 431-464.

Rosenzweig ML. 1995. Species Diversity in Space and Time. Cambridge, Cambridge University Press.

StatSoft. 2004. STATISTICA 7.0. http://www.statsoft.com.au/v7.htm. 3 Jul. 2009.

Vásquez-Vélez AI, Garzón S, Ascencio-Santofinio H. 2013. Caracterización florística asociada al hábitat de Dendrobatidae (Amphibia: Anurade), en la localidad de Piangüita (Bahía de Buenaventura), Pacifico colombiano. Boletín Científico Museos de Historia Natural 17: 17-32. 